\title{
Pengaruh Kemandirian Dan Dukungan Orangtua Pada Pembelajaran Jarak Jauh Terhadap Prestasi Belajar Dimasa Pandemi Covid-19
}

Supriyadi

\author{
Program Studi Pendidikan Ekonomi, Universitas Panca Sakti Bekasi
}

Correspondence author: supriyadiesbe@gmail.com

\begin{abstract}
ABSTRAK
Pandemi Covid-19 bukan saja memporakporandakan Indonesia akan tetapi hampir sebagian besar kehidupan umat manusia di seluruh dunia. Pembelajaran secara daring dan bekerja dari rumah dalam rangka pencegahan penyebaran COVID-19. Penelitian ini bertujuan untuk mengetahui Pengaruh Kemandirian dan Dukungan Orang Tua pada Pembelajaran Jarak Jauh (PJJ) terhadap Prestasi Belajar Siswa. Tulisan ini didasarkan dari Penelitian kuasi eksperimen dengan populasi seluruh siswa MTsN 7 Jakarta Timur yang berjumlah 617 siswa, Jumlah sampel penelitian merujuk pada tabel Isaac \& Michael dengan signifikansi 5\% sebanyak 221 siswa, menggunakan teknik Proportional random sampling. Data penelitian diperoleh dengan menggunakan instrumen yang valid dan reliabel. Analisis data menggunakan analisis regresi ganda. Disimpukan bahwa tidak terdapat pengaruh kemandirian pembelajaran jarak jauh terhadap prestasi belajar siswa, terdapat pengaruh dukungan orang tua pada pembelajaran jarak jauh terhadap prestasi belajar, terdapat pengaruh kemandirian dan dukungan orang tua pada pembelajaran jarak jauh secara simultan terhadap prestasi belajar.
\end{abstract}

Kata Kunci: Kemandirian, Dukungan Orang Tua, Prestasi Belajar, Pandemi Covid-19

\section{ABSTRACT}

The Covid-19 pandemic has not only devastated Indonesia but almost a large part of human life around the world. Learning online and working from home to prevent the spread of COVID-19. This study aims to determine the effect of independence and parental support on distance learning (PJJ) on student learning achievement. This paper is based on a quasi-experimental study with a population of all students at MTsN 7 East Jakarta, totaling 617 students. The number of research samples refers to the Isaac \& Michael table with a significance of 5\% as many as 221 students, using proportional random sampling technique. The research data were obtained using valid and reliable instruments. Data analysis using multiple regression analysis. It was concluded that there was no influence of independent distance learning on student achievement, there was an effect of parental support on distance learning on learning achievement, there was an effect of independence and parental support on distance learning simultaneously on learning achievement.

Keywords: Independence, Parental Support, Learning Achievement, Covid-19 Pandemic

\section{PENDAHULUAN}

Munculnya virus corona atau yang lebih dikenal dengan istilah COVID-19 menjadi masalah yang mendunia. Di Indonesia penyebaran COVID-19 pertama kali ditemukan pada tanggal 2 Maret 2020, hal ini disampaikan langsung oleh Presiden Republik Indonesia Joko Widodo 
(Nuraini, 2020), dan saat ini telah menginfeksi 23,165 orang dengan jumlah kematian 1,418 jiwa, dan jumlah pasien yang sembuh 5,877 orang (covid19.go.id, 2020).

Pemerintah melakukan berbagai upaya dalam memutus mata rantai penyebaran virus corona ini, salah satu upaya pemerintah dengan mengeluarkan peraturan pemerintah (PP) Nomor 21 tahun 2020 tentang Pembatasan Sosial Berskala Besar Dalam Rangka Percepatan Penanganan Covid-19 yang berakibat pada pembatasan berbagai aktivitas termasuk diantaranya sekolah. Peraturan pemerintah ini diikuti dengan dikeluarkannya Surat Edaran Mendikbud Nomor 36962/MPK.A/HK/2020 tentang Pembelajaran secara daring dan bekerja dari rumah dalam rangka pencegahan penyebaran Corona Virus Disease (COVID-19). Kementerian Agama mengeluarkan Keputusan Direktur Jenderal Pendidikan Islam Nomor 2791 Tahun 2020 Tentang Panduan Kurikulum Darurat Pada Madrasah. Pembelajaran di Madrasah juga terkena terdampak Covid-19. Kebijakan ini tentunya tidak hanya berdampak pada relasi guru dan murid selama BDR, namun juga pentingnya optimalisasi peran orang tua dalam pelaksanaan BDR.

Peran orang tua dalam mendampingi kesuksesan anak selama belajar di rumah menjadi sangat sentral, sekaitan dengan hal tersebut WHO, (2020) merilis berbagai panduan bagi orang tua dalam mendampingi putra-putri selama pandemi ini berlangsung yang meliputi tips pengasuhan agar lebih positif dan konstuktif dalam mendampingi anak selama beraktivitas di rumah. Prabhawani (2016) menyatakan bahwa pelaksanaan pendidikan merupakan tanggung jawab orang tua dan masyarakat sekitar, tidak hanya tanggung jawab lembaga pendidikan saja.

Lestari, (2012) menyatakan bahwa keluarga dilihat dari fungsinya yakni memiliki tugas dan fungsi perawatan, dukungan emosi dan materi, serta pemenuhan peranan tertentu. Proses pembelajaran yang biasanya dilakukan melalui tatap muka, kini diubah sepenuhnya menjadi sistem pembelajaran dalam jaringan (daring). Hal ini secara tidak langsung menyebabkan kepanikan pada berbagai pihak yang terkait dengan pendidikan anak. Dengan kata lain, masa ini bisa juga dibilang masa yang penuh ketidakpastian bagi beberapa anak.

Virus Disease (Covid-19) yang antara lain memuat arahan tentang proses bekerja dan belajar dari rumah (PBR) atau working and learning from home (WLFH). Pada intinya Surat tersebut Berkaitan dengan darurat dan bahaya Covid-19 terhadap aktivitas pendidikan secara luas, 
Menteri Pendidikan dan Kebudayaan Republik Indonesia telah menerbitkan beberapa Surat Edaran (SE). Pertama: SE Nomor 2 Tahun 2020 tentang Pencegahan dan Penanganan Covid19 di Lingkungan Kemendikbud, kedua: SE Nomor 3 Tahun 2020 tentang Pencegahan Covid19 pada Satuan Pendidikan, dan ketiga: SE Nomor 4 Tahun 2020 tentang Pelaksanaan Kebijakan Pendidikan dalam Masa Darurat Penyebaran Corona Virus Disease (Covid-19) yang antara lain memuat arahan tentang proses bekerja dan belajar dari rumah (PBR) atau working and learning from home (WLFH).

Kebijakan itu telah membuat pendidik berupaya untuk tetap memberikan layanan pendidikan kepada para peserta didik secara jarak jauh, dan ini telah melahirkan berbagai inovasi pembelajaran di berbagai lini pendidikan. Disadari ataupun tidak, praktik pendidikan kita telah mengalami revolusi yang luar biasa hanya dalam waktu yang sangat singkat. Menurut Nadiem Makarim (2020: vii) Pembelajaran daring justru mendorong kemampuan independent learning, sebagai kompetensi esensial di abad 21 ini. Di berbagai narasi, krisis seringkali dilihat sebagai faktor pendorong perubahan, a game changer. Krisis mendorong masyarakat untuk melakukan transformasi atas kesehariannya dan beradaptasi dengan hal-hal baru. Dorongan perubahan ini juga dirasakan di tengah krisis pandemi coronavirus disease (Covid-19) yang mulai dirasakan di Indonesia di bulan Maret 2020. (Angga Dwiartama dan Intan Ahmad, 2020: 79). Pembelajaran daring menjadi modus utama yang tidak pernah terbayangkan sebelumnya.

Pembelajaran jarak jauh saat ini telah, sedang, dan masih berjalan, maka diperlukan evaluasi proses pembelajaran tersebut. Evaluasi tersebut bukan hanya mata pelajaran yang diberikan, akan tetapi menyangkut semua aspek pendidikan tersebut. Hal ini antara lain adalah aspek proses belajar, guru, murid, metode, biaya, sarana dan parsarana, orang tua, serta berbagai aspek lainnya. Menurut Gusty dkk (2020: 95) kunci efektivitas dari pembelajaran daring adalah bagaimana seorang guru tetap kreatif adalah menyajikan pembelajaran secara menyenangkan dan mudah dimengerti sehingga siswa tidak merasa bosan. Penerapannya memerlukan kesiapan baik dari guru, siswa, sekolah dan orang tua.

Menurut Mohammad Ali dan Mohammad Asrori (2005: 114) kemandirian diartikan sebagai suatu kekuatan internal individu dan diperoleh melalui proses individuasi, yang berupa proses realisasi kedirian dan proses menuju kesempurnaan. Tokoh lain seperti Hamzah B. Uno (2006: 
77) mengartikan kemandirian sebagai kemampuan untuk mengarahkan dan mengendalikan diri dalam berpikir dan bertindak, serta tidak merasa bergantung pada orang lain secara emosional. Pada intinya, orang yang mandiri itu mampu bekerja sendiri, tanggung jawab, percaya diri, dan tidak bergantung pada orang lain.

Covid-19 telah mengubah segalanya. Termasuk pada peran orangtua dalam pendidikan anak. Sekolah yang selama ini tidak begitu melibatkan orang tua dalam proses pendidikan anak, mulai berbenah, setahap demi setahap menjalin komunikasi dan kolaborasi hal ini menuntut kepiawaian pimpinan dalam menerapkan manajemen yang baik di institusinya. Orangtua yang selama ini menganggap keterlibatan pada pendidikan anak hanya sebatas iuran dan rapat komite, mulai menyadari pentingya mendampingi dan mengawasi pendidikan anak baik di rumah maupun di sekolah. Orang tua harus dapat mengatur ritme dalam melakukan pengawasan saat anak belajar secara daring menggunakan gawainya, mengingat begitu bebasnya informasi positif dan negatif yang dapat diakses dengan mudah oleh seorang anak, oleh karena itu dibutuhkan manajemen pengawasan orang tua saat anak melakukan kegiatan belajar dari rumah.

Banyak penelitian-penelitian yang mengungkap tentang kemandirian dan dukungan orangtua terhadap prestasi belajar siswa akan, yang menarik dalam penelitian ini adalah kemandirian siswa yang dimaksud adalah kemandirian yang dilakukan saat pembelajaran jarak jauh dan dilakukan pada masa pandemi covid-19 dimana seluruh pembelajaran dilakukan melalui daring. Penelitian ini bertujuan untuk mengungkap: "Pengaruh Kemandirian dan Dukungan Orang tua pada Pembelajaran Jarak Jauh (PJJ) Terhadap Prestasi Belajar Dimasa Pandemi Covid-19".

\section{METODE PELAKSANAAN}

Metode penelitian yang digunakan dalam penelitian ini adalah metode survei. Populasi penelitian ini adalah seluruh peserta didik di Madrasah Tsanawiyah Negeri 7 Jakarta Timur berjumlah 617 peserta didik. Jumlah sampel penelitian merujuk pada tabel Isaac \& Michael dengan signifikansi 5\% sebanyak 221 siswa, menggunakan teknik Proportional random sampling. Pengumpulan data berupa skor diambil dengan menggunakan instrumen Kemandirian dan instrumen dukungan orang tua dalam bentuk instrumen skala sikap. Untuk skor prestasi belajar diambil dari nilai rata-rata raport semester genap tahun pelajaran 2019- 
2020. Instrumen kemandirian valid dan memiliki reliabilitas Alpha dimensi I 0,832, dan dimensi II sebesar 0,762, Instrumen dukungan orang tua juga valid dan reliabel dengan reliabilitas Alpha 0,831. Teknik analisis data menggunakan analisis regresi ganda dimana kemandirian sebagai variabel bebas $\left(\mathrm{X}_{1}\right)$ dan dukungan orang tua $\left(\mathrm{X}_{2}\right)$ untuk variabel terikat (Y) yaitu prestasi belajar. Hipotesa Penelitian ini: 1) Diduga terdapat pengaruh kemandirian terhadap prestasi belajar pendidikan agama islam dimasa pandemi covid-19?; 2) Diduga terdapat pengaruh dukungan orang tua terhadap prestasi belajar dimasa pandemi covid-19?; 3) Diduga terdapat pengaruh kemandirian dan dukungan orang tua secara simultan terhadap prestasi belajar peserta didik selama masa pandemi covid-19?. Analisis data penelitian dilakukan dengan terlebih dahulu mendeskripsiikan, selanjutnya dilakukan uji prasyarat dengan menguji normalitas dan homogenitas data, setelah didapatkan data yang normal dan homogen dilanjutkan dengan uji hipotesis dengan analisis regresi baik sebagian maupun secara simultan.

\section{HASIL PENELITIAN DAN PEMBAHASAN}

Deskripsi data skor Variabel Kemandirian Pembelajaran Jarak Jauh, Dukungan Orang Tua, Motivasi Belajar dan Prestasi Belajar disajikan pada tabel berikut

Tabel 1. Deskripsi Data Skor Variabel

\begin{tabular}{|c|c|c|c|c|}
\hline \multicolumn{5}{|c|}{ Statistics } \\
\hline & & $\begin{array}{c}\text { Kemandirian } \\
\text { Pembelajaran } \\
\text { Jarak Jauh }\end{array}$ & $\begin{array}{c}\text { Dukungan Orang } \\
\text { Tua }\end{array}$ & Prestasi Belajar \\
\hline \multirow{2}{*}{$\mathrm{N}$} & Valid & 217 & 217 & 217 \\
\hline & Missing & 0 & 0 & 0 \\
\hline \multicolumn{2}{|l|}{ Mean } & 23.3088 & 25.6406 & 80.7558 \\
\hline \multicolumn{2}{|c|}{ Std. Error of Mean } & .37297 & .33829 & .33779 \\
\hline \multicolumn{2}{|l|}{ Median } & 24.0000 & 25.0000 & 80.0000 \\
\hline \multicolumn{2}{|l|}{ Mode } & 25.00 & $24.00^{\mathrm{a}}$ & $79.00^{\mathrm{a}}$ \\
\hline \multicolumn{2}{|c|}{ Std. Deviation } & 5.49424 & 4.98329 & 4.97589 \\
\hline \multicolumn{2}{|l|}{ Variance } & 30.187 & 24.833 & 24.760 \\
\hline \multicolumn{2}{|l|}{ Range } & 27.00 & 26.00 & 23.00 \\
\hline \multicolumn{2}{|l|}{ Minimum } & 9.00 & 12.00 & 70.00 \\
\hline \multicolumn{2}{|l|}{ Maximum } & 36.00 & 38.00 & 93.00 \\
\hline \multicolumn{2}{|l|}{ Sum } & 5058.00 & 5564.00 & 17524.00 \\
\hline
\end{tabular}


Dari tabel diatas dapat dideskripsikan untuk variabel Kemandirian Pembelajaran Jarak Jauh ( $\left.\mathrm{X}_{1}\right)$ didapat nilai rata-rata (mean) 23.309, median 24, modus 25, standard deviasi 5.494 skor terendah 9 dan skor tertinggi 36. Berikut gambar histogram dan kurva variabel kemandirian pembelajaran jarak jauh $\left(\mathrm{X}_{1}\right)$.

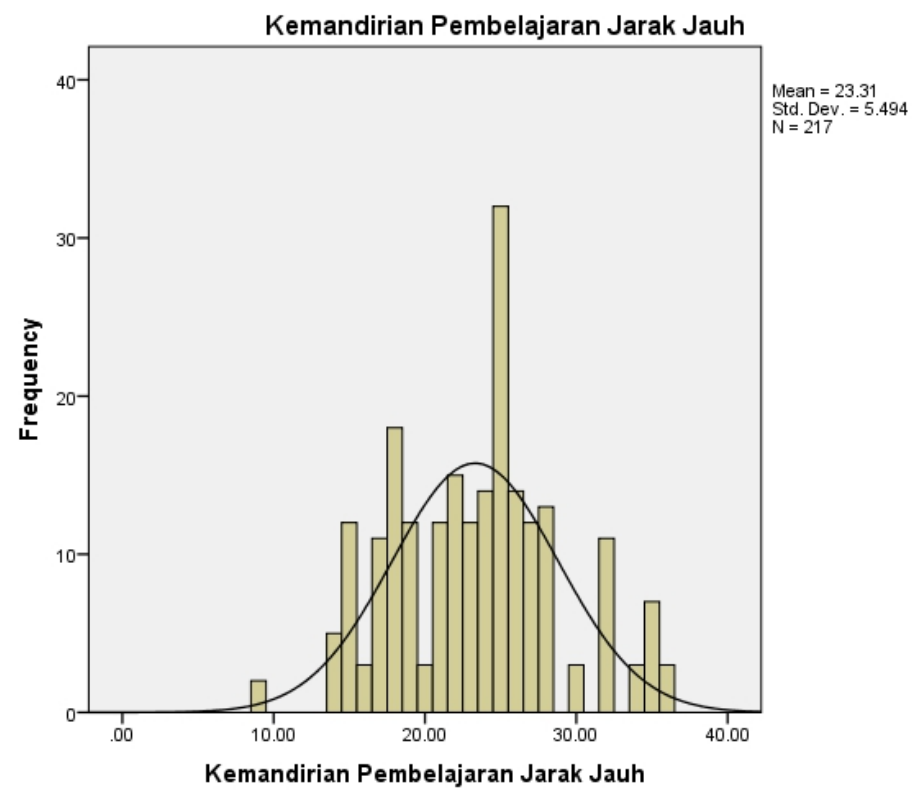

Gambar 1. Histogram dan kurva varibel Kemandirian Pembelajaran Jarak Jauh Variabel dukungan orang tua $\left(\mathrm{X}_{2}\right)$ didapat nilai rata-rata (mean) 25.641, median 25, modus 24, standard deviasi 4.893 skor terendah 12 dan skor tertinggi 38. Berikut gambar histogram dan kurva variabel Dukungan Orang Tua $\left(\mathrm{X}_{2}\right)$. 


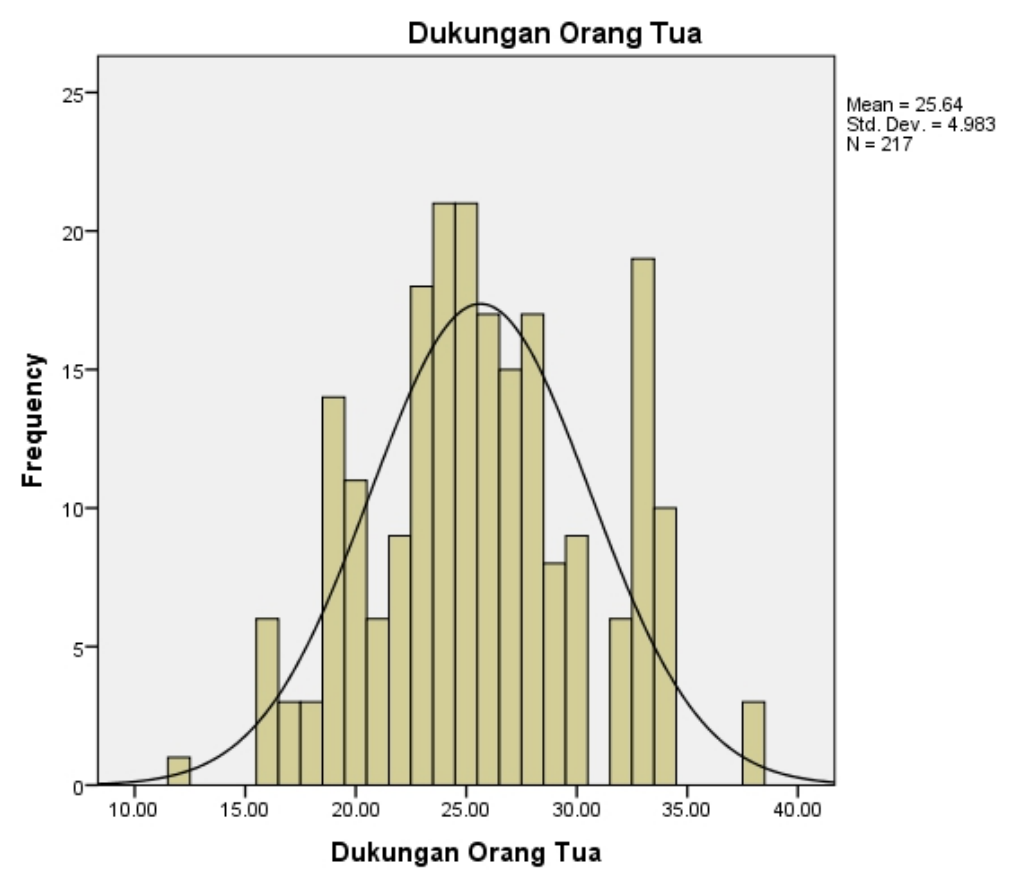

\section{Gambar 2. Histogram dan kurva varibel Dukungan Orang Tua}

Variabel prestasi belajar (Y) didapat nilai rata-rata (mean) 80.756, median 80, modus 79, standard deviasi 4.976 skor terendah 70 dan skor tertinggi 93. . Berikut gambar histogram dan kurva variabel Prestasi Belajar (Y).

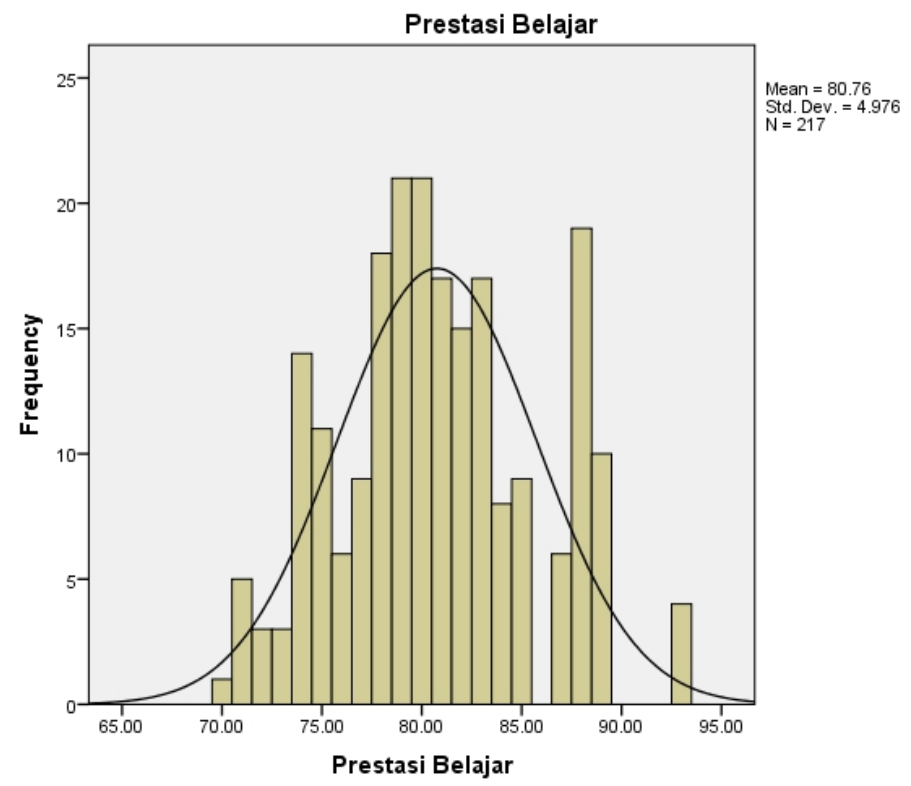

Gambar 3. Histogram dan kurva varibel Prestasi Belajar 
Uji Prasyarat dalam penelitian ini menguji normalitas dan homogenitas data penelitian, berikut hasi uji prasyarat normalitas data ketiga variabel dengan melakukan uji One-Sample Kolmogorov-Smirnov Test didapat hasil sebagai berikut:

\section{Tabel 2. Uji Prasyarat Uji Normalitas Data}

\begin{tabular}{|c|c|c|c|c|}
\hline \multicolumn{5}{|c|}{ One-Sample Kolmogorov-Smirnov Test } \\
\hline & & $\begin{array}{c}\text { Kemandirian } \\
\text { Pembelajaran Jarak } \\
\text { Jauh }\end{array}$ & $\begin{array}{c}\text { Dukungan Orang } \\
\text { Tua }\end{array}$ & Prestasi Belajar \\
\hline \multicolumn{2}{|l|}{$\mathrm{N}$} & 217 & 217 & 217 \\
\hline \multirow{2}{*}{ Normal Parameters ${ }^{\mathrm{a}, \mathrm{b}}$} & Mean & 23.3088 & 25.6406 & 80.7558 \\
\hline & Std. Deviation & 5.49424 & 4.98329 & 4.97589 \\
\hline \multirow{3}{*}{ Most Extreme Differences } & Absolute & .075 & .078 & .079 \\
\hline & Positive & .075 & .072 & .076 \\
\hline & Negative & -.073 & -.078 & -.079 \\
\hline \multicolumn{2}{|l|}{ Kolmogorov-Smirnov Z } & 1.104 & 1.143 & 1.169 \\
\hline \multicolumn{2}{|l|}{ Asymp. Sig. (2-tailed) } & .174 & .146 & .130 \\
\hline \multicolumn{5}{|c|}{ a. Test distribution is Normal. } \\
\hline \multicolumn{5}{|l|}{ b. Calculated from data. } \\
\hline
\end{tabular}

Dari tabel diatas skor Asymp. Sig. (2-tailed) untuk variabel Kemandirian Pembelajaran Jarak Jauh sebesar di dapat $\mathrm{p}$-value $=0.174>0.05$ dengan demikian variabel Kemandirian Pembelajaran Jarak Jauh berdistribusi normal. Variabel dukungan orang tua didapat p-value $=$ $0.146>0.05$ dengan demikian variabel dukungan orang tua berdistribusi normal dan untuk variabel prestasi belajar didapat $\mathrm{p}$-value $=0.130>0.05$ dengan demikian variabel prestasi belajar berdistribusi normal.

Uji Homogenitas dalam penelitian ini dengan melakukan Levene's Test of Equality of Error Variances didapat hasil uji sebagaiberikut: 


\section{Tabel 3. Uji Prasyarat Uji Homogenitas}

\begin{tabular}{|c|c|c|c|}
\hline \multicolumn{4}{|c|}{ Levene's Test of Equality of Error Variances ${ }^{a}$} \\
\hline \multicolumn{4}{|c|}{ Dependent Variable: Skor } \\
\hline $\mathrm{F}$ & dfl & $\mathrm{df} 2$ & Sig. \\
\hline 1.179 & 2 & 648 & .308 \\
\hline \multicolumn{4}{|c|}{$\begin{array}{l}\text { Tests the null hypothesis that the error variance of the dependent } \\
\text { variable is equal across groups. }\end{array}$} \\
\hline a. Design: Interce & elompok & & \\
\hline
\end{tabular}

Dari tabel diatas hasil uji levene menunjukan sig sebesar $0.308>0.05$ dengan demikian ketiga kelompok data berasal dari kelompok yang homogen.

1) Persamaan Linear Ganda dan Uji Signifikansi Koefisien Persamaan Regresi

Tabel 4. Coefficients

\begin{tabular}{|c|c|c|c|c|c|c|}
\hline \multicolumn{7}{|c|}{ Coefficients $^{\mathrm{a}}$} \\
\hline & \multirow{2}{*}{ Model } & \multicolumn{2}{|c|}{ Unstandardized Coefficients } & \multirow{2}{*}{$\begin{array}{c}\text { Standardized } \\
\text { Coefficients }\end{array}$} & \multirow{2}{*}{$\mathrm{t}$} & \multirow{2}{*}{ Sig. } \\
\hline & & B & Std. Error & & & \\
\hline \multirow{3}{*}{1} & (Constant) & 56.409 & .552 & & 102.143 &. \\
\hline & $\begin{array}{l}\text { Kemandirian Pembelajaran } \\
\text { Jarak Jauh }\end{array}$ & -.013 & .023 & -.015 & -.580 & .5 \\
\hline & Dukungan Orang Tua & .962 & .026 & .963 & 37.662 & .0 \\
\hline
\end{tabular}

a. Dependent Variable: Prestasi Belajar

Dari tabel di atas diperoleh konstanta $b_{0}=56.409$, koefisien regresi $b_{1}=-0.013$ dan $b_{2}=0.962$.

Sehingga persamaan regresi linear ganda adalah $\hat{\mathrm{Y}}=56.409+(-0.013) \mathrm{X}_{1}+0.962 \mathrm{X}_{2}$.

Hipotesis: $\mathrm{H}_{0}: \beta_{1} \leq \mathrm{vs} \mathrm{H}_{1}: \beta_{1}>0$ dan $\mathrm{H}_{0}: \beta_{2} \leq \mathrm{vs} \mathrm{H}_{1}: \beta_{2}>0$.

Dari hasil analisis di atas menunjukan harga statistik untuk untuk koefisien variabel $\mathrm{X}_{1}$ yaitu $\mathrm{t}_{\text {hit }}=-0.580$ dan $\mathrm{p}$-value $=0.563 / 2=0.281>0.05$ (uji pihak kanan), atau $\mathrm{H}_{0}$ diterima, yang bermakna kemandirian pembelajaran jarak jauh tidak berpengaruh positif terhadap prestasi belajar peserta didik. Hasil penelitian ini tidak sejalan dengan pendapat Nadiem Makarim 
(2020: vii) Pembelajaran daring justru mendorong kemampuan independent learning, sebagai kompetensi esensial di abad 21. Masih terdapat faktor atau variabel lain yang mempengaruhi prestasi belajar siswa. Dengan demikian hipotesa pertama dalam penelitian ini tidak didukung oleh data empiris.

Selanjutnya harga statistik untuk koefisien variabel $\mathrm{X}_{2}$ yaitu $\mathrm{t}_{\mathrm{hit}}=37.662$ dan $\mathrm{p}$-value $=$ $0.000 / 2=0.000>0.05$ (uji pihak kanan), atau $\mathrm{H}_{0}$ ditolak, yang bermakna dukungan orang tua berpengaruh positif terhadap prestasi belajar peserta didik. Hasil penelitian ini sejalan dengan pendapat Prabhawani (2016) menyatakan bahwa pelaksanaan pendidikan merupakan tanggung jawab orang tua dan masyarakat sekitar, tidak hanya tanggung jawab lembaga pendidikan saja. Dengan demikian hipotesa kedua penelitian ini didukung oleh data empiris.

\section{2) Uji Signifikansi Persamaan Regresi Ganda}

Tabel 5. Anova

\begin{tabular}{|c|c|c|c|c|c|c|}
\hline \multicolumn{7}{|c|}{ ANOVA $^{\mathrm{a}}$} \\
\hline & Model & Sum of Squares & $\mathrm{df}$ & Mean Square & $\mathrm{F}$ & Sig. \\
\hline \multirow{3}{*}{1} & Regression & 4870.620 & 2 & 2435.310 & 1091.574 & $.000^{\prime}$ \\
\hline & Residual & 477.436 & 214 & 2.231 & & \\
\hline & Total & 5348.055 & 216 & & & \\
\hline \multicolumn{7}{|c|}{ a. Dependent Variable: Prestasi Belajar } \\
\hline
\end{tabular}

Hipotesis:

$\mathrm{H}_{0}: \beta_{1}=\beta_{2}$ atau $\mathrm{H}_{0}: \beta_{1}-\beta_{2}=0$

$\mathrm{H}_{0}: \beta_{1} \neq \beta_{2}$ atau $\mathrm{H}_{0}: \beta_{1}-\beta_{2}=0$

Dari hasil analisis yang disarikan pada tabel ANOVA $^{\mathrm{b}}$ di atas diperoleh $\mathrm{F}_{\text {hit }}=1091.574$, dan $\mathrm{p}-$ value $=0.000<0.05$ atau hal ini berarti $\mathrm{H}_{0}$ ditolak. Artinya terdapat pengaruh linear variabel kemandirian pembelajaran jarak jauh dan dukungan orang tua dengan prestasi belajar peserta didik dimasa pandemi covid-19. Hal ini juga bermakna terdapat pengaruh secara bersama- 
sama (simultan) kemandirian pembelajaran jarak jauh dan dukungan orang tua terhadap prestasi belajar dimasa pandemi covid-19. Hasil penelitian ini sejalan dengan pernyataan Nadiem Makarim, Prabhawani dan lestari yang menyatakan kemandirian dan dukungan orang tua berpengaruh terhadap prestasi belajar. Dengan demikian hipotesa ketiga penelitian didukung oleh data empiris.

3) Uji Signifikansi Koefisien Korelasi Ganda

Tabel 6. Model Summary

\begin{tabular}{|c|c|c|c|c|c|c|c|c|c|}
\hline \multicolumn{10}{|c|}{ Model Summary } \\
\hline \multirow{2}{*}{ Model } & \multirow{2}{*}{$\mathrm{R}$} & \multirow{2}{*}{ R Square } & \multirow{2}{*}{$\begin{array}{c}\text { Adjusted R } \\
\text { Square }\end{array}$} & \multirow{2}{*}{$\begin{array}{l}\text { Std. Error of the } \\
\text { Estimate }\end{array}$} & \multicolumn{5}{|c|}{ Change Statistics } \\
\hline & & & & & $\begin{array}{l}\text { R Square } \\
\text { Change }\end{array}$ & F Change & df1 & $\mathrm{df} 2$ & $\begin{array}{c}\text { Sig. F } \\
\text { Change }\end{array}$ \\
\hline 1 & $.954^{\mathrm{a}}$ & .911 & .910 & 1.49366 & .911 & 1091.574 & 2 & 214 & .000 \\
\hline
\end{tabular}

Hipotesis Statistik:

$\mathrm{H}_{0}: \rho_{\mathrm{y} .12} \leq 0$

$\mathrm{H}_{1}: \rho_{\mathrm{y} .12}>0$

Uji signifikansi koefisien korelasi ganda diperoleh dari tabel model summary di atas. Koefisien korelasi ganda $\left(\mathrm{R}_{\mathrm{y} .12}\right)=0.954$ dan $\mathrm{F}_{\text {hit }}\left(\mathrm{F}_{\text {change }}\right)=1091.574$, serta $\mathrm{p}$-value $=0.000<$ 0.05 atau $\mathrm{H}_{0}$ ditolak. Dengan demikian, koefisien korelasi ganda antara $\mathrm{X}_{1}$ dan $\mathrm{X}_{2}$ dengan $\mathrm{Y}$ adalah berarti atau signifikan, sedangkan koefisien determinasi $\mathrm{R}$ Square $=0,911$, yang mengandung makna bahwa 91.1\% variabel Prestasi belajar (Y) dapat dijelaskan oleh kemandirian pembelajaran jarak jauh $\left(\mathrm{X}_{1}\right)$ dan dukungan orang tua $\left(\mathrm{X}_{2}\right)$, sehingga dapat disimpulkan bahwa pengaruh kemandirian pembelajaran jarak jauh dan dukungan orang tua secara bersama-sama terhadap prestasi belajar sebesar $91.1 \%$.

4) Uji Signifikansi Koefisiensi Korelasi Parsial

a) Korelasi antara kemandirian pembelajaran jarak jauh $\left(\mathrm{X}_{1}\right)$ dan prestasi belajar $(\mathrm{Y})$ dengan mengontrol pengaruh dukungan orang tua $\left(\mathrm{X}_{2}\right)\left(\mathrm{r}_{\mathrm{y} 1.2}\right)$ 
Tabel 7. Correlations Partial

\begin{tabular}{|c|c|c|c|c|}
\hline \multicolumn{5}{|c|}{ Correlations } \\
\hline \multicolumn{3}{|c|}{ Control Variables } & $\begin{array}{c}\text { Kemandirian } \\
\text { Pembelajaran Jarak }\end{array}$ & Prestasi Belajar \\
\hline \multirow{6}{*}{$\begin{array}{l}\text { Dukungan } \\
\text { Orang Tua }\end{array}$} & \multirow{3}{*}{$\begin{array}{l}\text { Kemandirian } \\
\text { Pembelajaran } \\
\text { Jarak Jauh }\end{array}$} & Correlation & 1.000 & -.040 \\
\hline & & Significance (1-tailed) & & .281 \\
\hline & & df & 0 & 214 \\
\hline & \multirow{3}{*}{ Prestasi Belajar } & Correlation & -.040 & 1.000 \\
\hline & & Significance (1-tailed) & .281 & \\
\hline & & df & 214 & 0 \\
\hline
\end{tabular}

Dari hasil analisi pada tabel di atas diperoleh $\left(\mathrm{r}_{\mathrm{y} 1.2}\right)=-0.040$ dan $\mathrm{p}$-value $=0.281>$ 0.05 atau $\mathrm{H}_{0}$ diterima. Dengan demikian, koefisien korelasi antara kemandirian pembelajaran jarak jauh $\left(\mathrm{X}_{1}\right)$ dan prestasi belajar $(\mathrm{Y})$ dengan mengontrol variabel dukungan orang tua $\left(\mathrm{X}_{2}\right)$ adalah tidak signifikan.

b) Korelasi antara dukungan orang tua $\left(\mathrm{X}_{2}\right)$ dan prestasi belajar $(\mathrm{Y})$ dengan mengontrol pengaruh kemandirian pembelajaran jarak jauh $\left(\mathrm{X}_{1}\right)\left(\mathrm{r}_{\mathrm{y} 2.1}\right)$

Tabel 8. Correlations Partial

\begin{tabular}{|c|c|c|c|c|}
\hline \multicolumn{5}{|c|}{ Correlations } \\
\hline \multicolumn{3}{|c|}{ Control Variables } & Prestasi Belajar & Dukungan Orang \\
\hline \multirow{6}{*}{$\begin{array}{l}\text { Kemandirian } \\
\text { Pembelajaran } \\
\text { Jarak Jauh }\end{array}$} & \multirow{3}{*}{ Prestasi Belajar } & Correlation & 1.000 & .932 \\
\hline & & Significance (1-tailed) & & .000 \\
\hline & & $\mathrm{df}$ & 0 & 214 \\
\hline & \multirow{3}{*}{$\begin{array}{l}\text { Dukungan Orang } \\
\text { Tua }\end{array}$} & Correlation & .932 & 1.000 \\
\hline & & Significance (1-tailed) & .000 & \\
\hline & & df & 214 & 0 \\
\hline
\end{tabular}


Dari hasil analisi pada tabel di atas diperoleh $\left(\mathrm{r}_{\mathrm{y} 2.1}\right)=0.932$ dan $\mathrm{p}$-value $=0.00<0.05$ atau $\mathrm{H}_{0}$ ditolak. Dengan demikian, koefisien korelasi antara dukungan orang tua $\left(\mathrm{X}_{2}\right)$ dan prestasi belajar $(\mathrm{Y})$ dengan mengontrol variabel kemandirian pembelajaran jarak jauh $\left(\mathrm{X}_{1}\right)$ adalah signifikan.

\section{KESIMPULAN}

Dari hasil penelitian tersebut di atas maka dapat disimpulkan bahwa: 1) Kemandirian siswa pada pembelajaran jarak jauh tidak berpengaruh terhadap prestasi belajar; 2) Dukungan orang tua pada pembelajaran jarak jauh berpengaruh terhadap prestasi belajar; 3) Kemandirian dan dukungan orang tua pada pembelejaran jarak jauh secara bersama-sama berpengaruh terhadap prestasi belajar.

Dari simpulan hasil penelitian ini maka dapat direkomendasikan bahwa:1) Orang tua harus mengambil peran dalam pembelajaran jarak jauh; 2) pengawasan dan perhatian orang tua pada pembelajaran jarak jauh diperlukan oleh peserta didik; 3) diperlukan sinergitas antara siswa, orang tua, guru, kepala madrasah dan komite dalam pembelajaran jarak jauh.

\section{REFERENSI}

Ahmad, I. F. (2020). Asesmen Alternatif Dalam Pembelajaran Jarak Jauh Pada Masa Darurat Penyebaran Coronavirus Disease (Covid-19) Di Indonesia. PEDAGOGIK: Jurnal Pendidikan, 7(1), 195-222.

DOI: https://doi.org/10.33650/pjp.v7i1.1136

Angga Dwiartama dan Intan Ahmad, 2020 "Tantangan dan Peluang Kuliah Daring di Perguruan Tinggi: Refleksi dalam Perspektif Pedagogi" dalam Potret Pendidikan Tinggi Di Masa Covid-19, Editor: Tian Belawati, dan Nizam. Jakarta: Direktorat Jenderal Pendidikan Tinggi, h. $79-93$.

Atsani, K. L. G. M. Z. (2020). Transformasi media pembelajaran pada masa Pandemi COVID-19. Al-Hikmah, 1(1), 82-93.

Cahyati, N., \& Kusumah, R. (2020). Peran Orang Tua Dalam Menerapkan Pembelajaran Di Rumah Saat Pandemi Covid 19. Jurnal Golden Age, 4(01), 152-159.

Fuad Abdul Hamied, 2020, Kuliah Daring di Era Covid-19: Perspektif Evaluasi Hasil Belajar, dalam Potret Pendidikan Tinggi Di Masa Covid-19, Editor: Tian Belawati, dan Nizam. Jakarta: Direktorat Jenderal Pendidikan Tinggi, h. 249 - 270). 
Gusty, S., Nurmiati, N., Muliana, M., Sulaiman, O. K., Ginantra, N. L. W. S. R., Manuhutu, M. A., ... \& Hastuti, P. (2020). Belajar Mandiri: Pembelajaran Daring di Tengah Pandemi Covid-19. Yayasan Kita Menulis.

Handayani, L. (2020). Keuntungan, Kendala dan Solusi Pembelajaran Online Selama Pandemi Covid-19: Studi Ekploratif di SMPN 3 Bae Kudus. Journal of Industrial Engineering \& Management Research, 1(2), 15-23.

DOI: https://doi.org/10.7777/jiemar.v1i2.36

Kurniasari, A., Pribowo, F. S. P., \& Putra, D. A. (2020). ANALISIS EFEKTIVITAS PELAKSANAAN BELAJAR DARI RUMAH (BDR) SELAMA PANDEMI COVID-19. Jurnal Review Pendidikan Dasar: Jurnal Kajian Pendidikan dan Hasil Penelitian, 6(3), 246253.

DOI: http://dx.doi.org/10.26740/jrpd.v6n3.p246-253

Maryani, K. (2020). Penilaian dan Pelaporan Perkembangan Anak Saat Pembelajaran di Rumah di Masa Pendemi Covid-19. Murhum, 41-52.

Nurkolis, N., \& Muhdi, M. (2020). Keefektivan Kebijakan E-Learning berbasis Sosial Media pada PAUD di Masa Pandemi Covid-19. Jurnal Obsesi: Jurnal Pendidikan Anak Usia Dini, 5(1), 212-228.

DOI : https://doi.org/10.31004/obsesi.v5i1.535

Pramada, R., BURSTIANDO, R., \& PUTRA, R. P. (2020). HUBUNGAN DUKUNGAN ORANG TUA DENGAN MOTIVASI BELAJAR SISWA DALAM MENGIKUTI PEMBELAJARAN PENJAS SECARA DALAM JARINGAN (DARING) SAAT PANDEMI COVID-19 DI MI SURYA UTAMA AL FAJAR DESA KEREP (Doctoral dissertation, Universitas Nusantara PGRI Kediri).

Qowaid Qowaid, Dedi Junaedi, Moh Romli, Amie Primarni (2020) Analisis Persepsi Civitas Akademika Terhadap Implementasi Perkuliahan E-Learning Selama Pandemi Covid19: Studi Kasus IAI -N Laa Roiba Tahun 2020. Religious Education Social Journal, 2 (2), 114 $-141$.

DOI: https://doi.org/10.47467/reslaj.v2i2.144

Saifulloh, A. (2020). Manajemen Pembelajaran dalam Meningkatkan Efektivitas Proses Belajar Mengajar di Masa Pandemi Covid-19. Bidayatuna: Jurnal Pendidikan Guru Mandrasah Ibtidaiyah, 3(02), 285-312. doi:10.36835/bidayatuna.v3i02.638.

Sa'dullah, M. (2020). PANDEMI COVID-19 DAN IMPLIKASINYA TERHADAP PEMBELAJARAN PENDIDIKAN AGAMA ISLAM (STUDI KASUS PADA SISWA SMP N 1 BANYUBIRU KABUPATEN SEMARANG) TAHUN 2020 (Doctoral dissertation, IAIN SALATIGA).

Setiawan, D., \& Wicaksono, S. L. (2020). Evaluasi Usability Google Classroom Menggunakan System Usability Scale. Walisongo Journal of Information Technology, 2(1), 71-78.

DOI: $\underline{\text { http://dx.doi.org/10.21580/wjit.2020.2.1.5792 }}$ 